\title{
Development prospects of primary education integration (on the example of exact and natural sciences)
}

\section{Navruza SALOKHITDINOVA ${ }^{1}$}

Termez State University

\begin{tabular}{l} 
ARTICLE INFO \\
\hline Articlehistory: \\
Received June 2021 \\
Received in revised form \\
20 June 2021 \\
Accepted 15 July 2021 \\
Available online \\
15August 2021
\end{tabular}

\footnotetext{
Keywords:

integration,

subject,

pedagogical technology,

innovation,

interdisciplinary links, training

process, education, student,

teacher, integrational approach,

pedagogical integration.
}

\begin{abstract}
This article discusses current state of science integration in primary education reflected in the literature and relevant sources review. In addition, integration of science content review given its meaning and function fully expresses the essence of education. The article also emphasizes importance of correctly established student - teacher relationships in the primary education process and their significant effect on education quality. The research work also puts forward the idea of designing the disciplines integration process on the basis of the opinion of teachers and argumentation of the result.
\end{abstract}

2181-1415/C 2021 in Science LLC.

This is an open access article under the Attribution 4.0 International (CCBY 4.0) license (https://creativecommons.org/licenses/by/4.0/deed.ru)

\section{Бошланғич таълим интеграциясининг истиқболлари (аниқ ва табиий фанлар мисолида) \\ ривожланиш}

\author{
Калитсуйлар: \\ интеграция, \\ субъект, \\ педагогик технология, \\ инновация, \\ фанлараро алоқадорликлар, \\ ўқув жараёни, \\ таълим, \\ талаба, \\ ўқитувчи, \\ интеграцион ёндашув, \\ педагогик интеграция.
}

\begin{abstract}
АННОТАЦИЯ
Ушбу мақолада бошланғич таълимда фанлараро интеграциянинг хозирги холати адабиётлар ва тегишли манба-лар шарқида акс эттирилган. Бундан ташқари, унинг мазмуни ва вазифаси берилган фан мазмуни шархини интеграциялаш таълим мохиятини тўлиқ ифодалайди. Мақолада, шунингдек, бошланғич таълим жараёнида тўғри ташкил этилган талаба-ўқитувчи муносабатларининг ахамияти ва уларнинг таълим сифатига бўлган таъсири хам таъкидланади. Тадқиқот ишида, шунингдек, ўқитувчиларнинг фикри ва натижанинг аргументацияси асосида фанларни интеграция қилиш жараёнини лойихалаш ғояси хам илгари сурилади.
\end{abstract}

\footnotetext{
1 Trainee lecturer, Termez State University, Termez, Uzbekistan.

E-mail: saloxitdinovanavruza@gmail.com.
} 


\section{Перспективы развития интеграции начального образования (на примере точных и естественных наук)}

\author{
Ключевые слова: \\ интеграция, \\ субъект, \\ педагогические \\ технологии, \\ инновации, \\ междисциплинарные \\ связи, \\ учебный процесс, \\ образование, \\ студент, \\ преподаватель, \\ интеграционный подход, \\ педагогическая \\ интеграция.
}

\begin{abstract}
АННОТАЦИЯ
В данной статье рассматривается современное состояние интеграции науки в начальное образование, отраженное в обзоре литературы и соответствующих источников. Кроме того, интеграция обзора содержания науки с учетом ее смысла и функции в полной мере выражает сущность образования. В статье также подчеркивается важность правильно установленных отношений между учеником и учителем в процессе начального образования и их существенное влияние на качество образования. В исследовательской работе также выдвигается идея проектирования процесса интеграции дисциплин на основе мнения преподавателей и аргументации результата.
\end{abstract}

\section{INTRODUCTION}

Integration of theoretical and practical problems of modern primary education is very important in the context of new social requirements. Today, development of science and huge changes in production arise requirements that set up new tasks in school education. Modern education system is aimed at teaching foundations of science at the highest level, and bringing up the youth with progressive thinking, a whole understanding and imagination of the world and ability to correctly understand events around them. The present list of disordered subjects at school leads to the formation of fragmental outlook of school-leavers. Modern science is more susceptible to the integration of economic and political science.

Foundation for a serious relation to environment istaught in primary schools. Thus, basis for development and renewal of all aspects of economic education in primary schools is created. Elementary students in the class should also correspond characteristics and course requirements in order to identify key issues of such renewal.

\section{REFERENCES AND METHODOLOGY}

Integration stands for interdisciplinary connection. Cores of interdisciplinary coherence arose from the need to show and explain nature in its entirety in textbooks. Integration of learning process and its importance are shown in the works of great pedagogues as follows:

The great didactician Jan Amos Comenius stated: "Everything connected with each other must be studied in a similar way" [1: 260]. The idea of interdisciplinary connection was later applied by many educators that contributed to its development and generalization.

According to D. Locke: "In determining the content of education, one discipline should be supplemented with elements and facts of other disciplines" [2:123].

Commenting on the issue of interdependence in textbooks, I.V. Pestalossi says: "One should realize natural interconnection of disciplines when studying into them". Pestalossi also argued that distancing of one science from another is even dangerous. 
Speaking about integration didactic impact on psychological-pedagogical relationship of the pedagogy of the past, K.D. Ushenskiymentions: "Any knowledge and ideas offered by science should be reported as wide outlook about world and life and enlightenment" K.D. Ushensky had a great influence on the development of the theory of interdisciplinary connection.

H.V. Stoyunin, N.F. Bunakov, V.I. Vodovozov and other teachers also worked effectively for the sake of methodology development. Importance of interdisciplinary involvement, or integration, have been considered by a lot of teachers. In particular, in the view of I.D. Zverev, interdisciplinary connection develops students' thinking skills, increases their independence. It also builds their work skills and competencies along with developing their interest in science and is a great help in fostering an environmental culture.

At the beginning of the twentieth century, several interesting pedagogical researches were carried out into integration and a certain progress was achieved, especially in the field of primary education. At present also, integration is paid a special attention. Speaking of integration in secondary schools, we mean new pedagogical research,creative growth within a teaching team. When teaching through integration,the following should be paid special attention:

- each course should be purposeful;

- involvement in sciences should be connected across the selected material on the subject;

- identifying the ways of increasing students' activity and involvement;

- the course should be focused on not only teaching, but also on realizing humanitarian aspects;

- depending on the theme of the subject, attention should also be paid to forming scientific knowledge of society, human mind and development, belief in the future of our republic;

- In general, integrationof classes should be compatible with each other.

\section{RESULTS}

In XIX - XX centuries, there was carried out wide pedagogical research into creation of integral course on getting primary classes acquainted with natural environment. In particular, these works were associated with the names of such scholars as A.Y. Gerd, D.N. Kaygorodov, A.P. Pavlov, V.N. Maksimova, S.P. Baranova, M.N. Skatkin, who recommended inclusion of an integral course on nature and environment into primary education $[4 ; 266]$.

A number of works were devoted to correlations between sciences in primary education. These problems are in the recent development zone of transition to integration of subjects. The process of mastering the content of these areas of education and knowledge, skills and their application have not been studied theoretically and practically.

Integration of elementary school subjects has undergone little research and there is a lot of controversy among scholars about the nature of these relationships. During integration interconnectednessrises and gets in order, as well as elements of this system is regulated. How can these general rules be applied in school education? Modern didactic methodology emphasizes that the success of teaching and educating students depends on the formation of their understanding of the unity of the world, the need to conduct their activities on the basis of natural common laws, while forming the ability to solve 
interdisciplinary links in science. Integration in education can be seen through systemic approach to the contents of school subject.

Several levels of integration can be distinguished:

- initial - combining elementary knowledge of nature;

- middle - integration of subject divisions;

- final -integration of the last stage of biology study.

Knowledge of any science is achieved through recognition of new facts and concepts and by comparing them with the same knowledge. The simplest generalization of knowledge always takes place but it would be the best if the acquired knowledge were combined with the knowledge that is close to it. This results in arising of students' analytical and generalization skills. Perception within the system ensures that students understand the whole system of sciences, that there is a wide use of knowledge within studied disciplines. Perception Within the system reflects connections between time, environment and numbers. Interdisciplinary perceptions are considered to be the highest level of mental activity. They combine different knowledge systems allowing us to realize the diversity of an event or process. General concepts emerge based on this knowledge. Formation of interdisciplinary perceptions allows one to use, subordinate knowledge and to identify gaps in it. At the same, Yu.M. Kolyagin and O.L. Aleksenko reflect their negative attitude towards interdisciplinary integration, by stating that "Limited number of academic subjects cannot reflect large amounts of knowledge about real world and interconnectedness of elements [5: 136].

Psychology researchers E.N. Kabanova and Miller noted that "an important indicator of mental development is the process of transferring skills and abilities on the basis of an aim that is new to the teacher himself". Focusing on the importance of integration in primary school education, L.P. Elkanin suggests integration as a form of making classes effective and rising interscience connections to a new level [6: 182].

The purpose of education integration is the principle to ensure an individual's harmonic development. As French scientist J. Dyu said "Nowadays, there are changes in education aimed at moving the center of gravity. These changes are very similar to Copernicus revolution that moved the center of the universe from the Earth to the Sun. In our example, children (students) are like the Sun and teaching tools will go round them. Children are the center of tools formed around them" [7: 437].

Integration as a pedagogical phenomenon has two traditions: first of them is that some school subjects are integral initially. Most of all, this integration is within the science: for example, literacy classes (reading and writing) is an integral course from the very beginning. School literature class was also based of a single goal. Such a link between training to improve the skills of reading, literature, creative thinking and creativity resulted in combining skills, that is a particular proof of our point of view. Today, however, a new approach has begun to combine school disciplines. The problem of integration of interrelated subjects is being addressed now.

How can education integration be characterized?

"Integration" concept implemented in the educational process has two meanings:

- get schoolchildren understand environment and the world around us as a whole (in this case integration as a goal of education);

- getting general aspects of scientific knowledge closer to each other (in this case integration is regarded as a teaching tools).

Nowadays, the issue of education integration is regarded as one of directions that will help to effectively solve duties of teachers and students. 


\section{CONCLUSION}

The problem of integration of education and upbringing at the primary school is important and actual both theoretically and practically. Currently, the issue of education integration in natural knowledge is of great importance and this will help to unify other types of knowledge. Such an approach is well known and widely used in the practice of foreign schools. The issue is to integrate several interrelated subjects not only at primary, but also medium and higher levels of school education. This integrated science is supposed to include a number of social-economic and moral-aesthetic ideas and concepts, that are necessary to understand unity of the nature and the society.

Foreign experience shows that integrated subjects helping to get acquainted with nature and society are included in school curricula of many countries. These integrated subjects with environmental focus as a main toolindicates that students' environmental responsibility is being formed.

\section{REFERENCES:}

1. Tukhtaev A., Hamidov A. "Fundamentals of Ecology and Nature Protection". Tashkent: "O'qituvchi", 1994. - P. 260.

2. Shodimetov Yu.Sh. "Introduction to Social Ecology". Part 1. - Tashkent: "O'qituvchi”, 1994. - P. 123.

3. Turdikulov 0. "Man and the Air" Teacher's Guide. Tashkent. "Yozuvchi", 2002. - P. 34.

4. Bukhareva L.N. "Integration of school subjects at primary school" (Nachalnaya shkola № 8 1991). - P. 266.

5. Kolyagin Yu.M., Alekseenko 0.J. "Integration of school education" // Nach. shkola. - 1990. - № 9. - P. 136.

6. Mavlonova R., Rakhmatkulova N., "Integration of primary education". Tashkent. 2011. - P. 182.

7. Omonov H.T. "The role of integration and differentiation of sciences in the creation of a general scientific picture of the world" // Social sciences and humanities in the education system. - 2007. - № 3. - P. 437. 